\title{
Determinant factors affecting the improvement of education index
}

\author{
Jalil Setiawan Jamal*; Muslim Salam; A. Nixia Tenriawaru; Didi Rukmana; Muhammad Hatta \\ Jamil; Saadah \\ Universitas Hasanuddin \\ Jl. Perintis Kemerdekaan Km. 10, Tamalanrea Indah, Tamalanrea, Kota Makassar, Sulawesi Selatan \\ 90245, Indonesia \\ *Corresponding Author. E-mail: jalilsetiawan357@gmail.com
}

\begin{tabular}{ll} 
ARTICLE INFO & ABSTRACT \\
\hline $\begin{array}{l}\text { Article History } \\
\text { Submitted: }\end{array}$ & $\begin{array}{l}\text { The Human Development Index (HDI) of the Selayar Islands Regency experienced } \\
\text { an insignificant improvement. The low education index causes the low HDI achieve- } \\
\text { 17 April 2021 }\end{array}$ \\
$\begin{array}{l}\text { Revised: } \\
\text { 24 June 2021 }\end{array}$ & $\begin{array}{l}\text { is lower than the health index and the expenditure index. Therefore, it is essential to } \\
\text { improve the education index. This study aims to analyze the factors that influence the } \\
\text { Accepted: }\end{array}$ \\
$\begin{array}{l}\text { education index. This study uses secondary data in panel data, a combination of time- } \\
\text { series data from 2014 to 2019, and cross-section data from 11 sub-districts. Panel data }\end{array}$ \\
$\begin{array}{l}\text { Keywords } \\
\text { to measure the factors that affect the Education Index were analyzed using regression } \\
\text { education index; teacher } \\
\text { to student ratio; school to } \\
\text { student ratio; class to } \\
\text { student ratio }\end{array}$ & $\begin{array}{l}\text { negative effect on the education index, the class to student ratio at elementary school } \\
\text { has a positive effect on the education index, while the school to student ratio at ele- } \\
\text { mentary school, school to student ratio at junior high school, class to student ratio at }\end{array}$ \\
Scan Me: & $\begin{array}{l}\text { junior high school and teacher to student ratio at junior high school do not affect the } \\
\text { education index. }\end{array}$
\end{tabular}

Scan Me:

This is an open access article under the CC-BY-SA license.

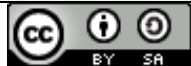

How to cite:

Jamal, J., Salam, M., Tenriawaru, A., Rukmana, D., Jamil, M., \& Saadah, S. (2021). Determinant factors affecting the improvement of education index. Jurnal Penelitian dan Evaluasi Pendidikan, 25(1), 88-96. doi:https:/ / doi.org/10.21831/pep.v25i1.40160

\section{INTRODUCTION}

Education, according to Ki Hajar Dewantara, is a way of life that can guide a child in utilizing all natural strengths and potentials that will bring maximum safety and happiness as a human being or as a member of society (Sugiarta et al., 2019). Regional development performance can be measured through the performance of the education sector in the region. Thus, according to Chamadi (Sukarsa, 2012), several indicators to measure the quality of education in an area include (1) the teacher to student ratio, which is the ratio between the number of teachers by the number of students in certain education level; (2) the school to student ratio, which is the ratio between the number of schools and the number of students at a certain level of education; and (3) the class to student ratio is the ratio between the number of classrooms and the number of students at a certain level of education.

One of the indicators to measure the success of education development is the education index (Mahendra et al., 2016). The Central Bureau of Statistic (Badan Pusat Statistik or BPS) explains that Education Index is a combination of two indicators of education in which the average length of schooling is described as the number of years needed by the population in formal education and expectancy of schooling that is described as a school which the child expects at a certain age in the future (Mahendra et al., 2016). 
Education Index on Selayar Islands Regency has experienced an insignificant improvement over the past decade. In line with this, the Education Index achievements of Selayar Islands Regency in 2018, when compared to 24 Regencies/Cities in South Sulawesi Province, are in the 19th or sixth lowest rank above Jeneponto, Bantaeng, Takalar, Bone, and Wajo Regency. This achievement can be seen in Figure 1 and Figure 2.

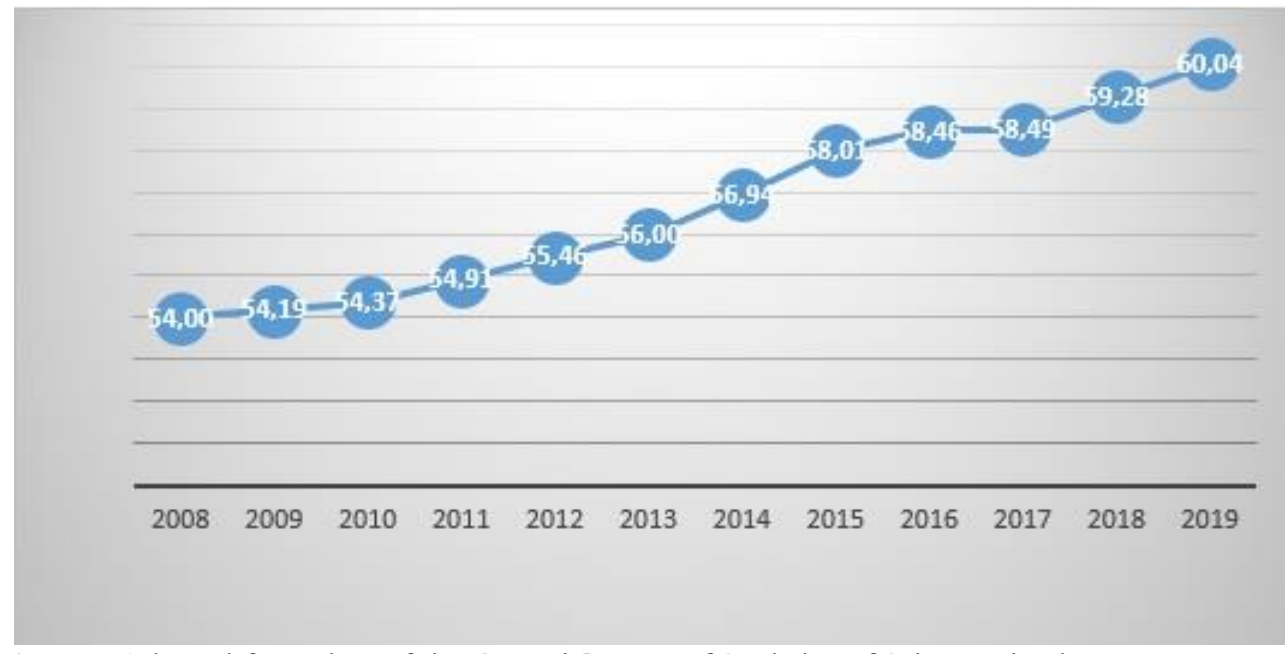

Source: Adapted from data of the Central Bureau of Statistics of Selayar Island Regency

Figure 1. The Education Index of Selayar Island Regency

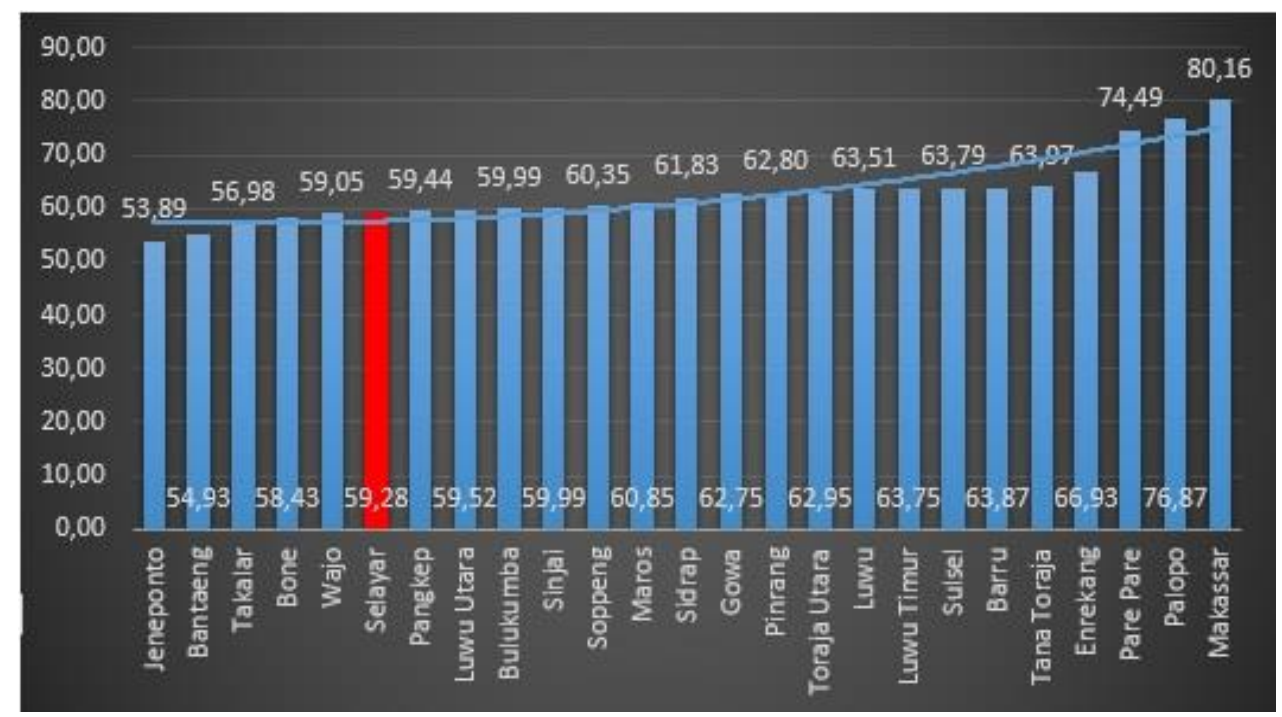

Source: Adapted from data of the Central Bureau of Statistics of South Sulawesi Province

Figure 2. The Education Index of Cities/Regencies in South Sulawesi Province on 2018

The education index is one of three composite indexes of the Human Development Index (HDI) besides the health index and expenditure index (Mirza, 2011). When viewed from the achievement of these three composite indexes, it can be concluded that the achievement of the education index is lower than the achievement of the Health Index and the Expenditure Index, as shown in Table 1. The low achievement of the education index causes the low HDI achievement of the Selayar Islands Regency. It happens because, as one of the composite indexes of the HDI, the Education Index is very influential on the HDI itself. The improvement of the Education Index has a positive and significant correlation with the improvement of HDI (Cahill, 2005). The Education Index also has a significant and positive effect on HDI (Lestari \& Sanar, 2018). 
90 - Jalil S. Jamal, Muslim Salam, A. Nixia Tenriawaru, Didi Rukmana, Muhammad H. Jamil, \& Saadah

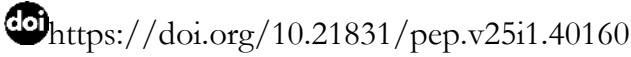

Table 1. Results of the Composite HDI Index for Selayar Islands Regency in 2010-2019

\begin{tabular}{ccccc}
\hline Year & Education Index & Health Index & Expenditure Index & HDI \\
\hline 2008 & 54.00 & 70.62 & 60.20 & 61.23 \\
2009 & 54.19 & 70.65 & 61.83 & 61.86 \\
2010 & 54.37 & 70.67 & 62.49 & 62.15 \\
2011 & 54.91 & 70.72 & 62.96 & 62.53 \\
2012 & 55.46 & 70.78 & 63.31 & 62.87 \\
2013 & 56.00 & 70.82 & 63.53 & 63.16 \\
2014 & 56.94 & 70.83 & 63.96 & 63.66 \\
2015 & 58.01 & 71.17 & 64.46 & 64.32 \\
2016 & 58.46 & 71.27 & 65.77 & 64.95 \\
2017 & 58.49 & 71.37 & 66.98 & 65.39 \\
2018 & 59.28 & 71.72 & 67.75 & 66.04 \\
2019 & 60.04 & 72.23 & 69.07 & 66.91 \\
\hline
\end{tabular}

Source: Adapted from data of the Central Bureau of Statistics of Selayar Islands Regency

Based on those explanations, this study aims to analyze the factors that affect the improvement of the education index. To answer the research objectives, it is necessary to formulate a research hypothesis. The formulation of the hypothesis in this study is based on the problems described previously and is based on the study and analysis of several previous studies related to this research. The research hypothesis that is formulated can be explained as follows: "The variables of the teacher to student ratio at elementary school, the teacher to student ratio at junior high school, the school to student ratio at elementary school, the school to student ratio at junior high school, the class to student ratio at elementary school, the class to student ratio at junior high school respectively and or simultaneously have a significant influence to the Education Index improvement in the Selayar Islands Regency".

\section{RESEARCH METHOD}

This research employed a quantitative method approach. In order to analyze the factors affecting the Education Index, the research variables are the teacher to student ratio at elementary school (X1), the teacher to student ratio at junior high school (X2), the school to student ratio at elementary school (X3), the school to student ratio at junior high school (X4), the class to student ratio at elementary school (X5), the class to student ratio at junior high school (X6) as the independent variable, and the Education Index as the dependent variable. The type of data required is secondary data in the form of panel data formed by time-series data from 2014 until 2019 with cross-section data in 11 sub-districts.

Regression analysis technique was used to analyze the factors affecting the Education Index using panel data. Panel data regression analysis was started by selecting the best panel data model in the study. Widarjono (Sunarya, 2016) says that the estimation model with panel data uses three approaches: Common Effect Model (CEM), Fixed Effect Model (FEM), and Random Effect Model (REM). The best model of the three approaches was estimated by the Chow test to choose between the CEM and FEM models and the Hausman test to choose between the FEM and REM models. After the panel data model was determined, a regression equation was generated, followed by a hypothesis test in the form of the F statistical test, R2 statistical test, and $t$ statistical test. The regression equation is shown in Formula (1), where $I P_{i t}=$ Education Index for the $i$-subdistrict in the t-year, $X_{1 i t}=$ the teacher to student ratio at elementary school for i-subdistrict in t-year, $X_{2 i t}=$ the teacher to student ratio at junior high school for i-subdistrict in t-year, $X_{3 i t}=$ the school to student ratio at elementary school for i-subdistrict in t-year, $X_{4 i t}=$ the school to student ratio at junior high school for i-subdistrict in t-year, $X_{5 i t}=$ the class to student ratio at elementary school for i-subdistrict in t-year, $X_{6 i t}=$ the class to student ratio at junior high school for $\mathrm{i}$-subdistrict in t-year, $\beta_{0}=$ intercept coefficient, $\beta_{n}: n=1,2, \ldots, 6$ $=$ regression parameters, and $\varepsilon_{t}=$ error term. In addition, Ajija (2011), Aulia (2004), Gujarati 
(2003), Verbeek (2000), and Wibisono (2005) state that in regression analysis with panel data, it is unnecessary to test classical assumptions as an implication of the various advantages possessed by panel data compared to time series data or cross-section data.

$$
I P_{i t}=\beta_{0}+\beta_{1} X_{1 i t}+\beta_{2} X_{2 i t}+\beta_{3} X_{3 i t}+\beta_{4} X_{4 i t}+\beta_{5} X_{5 i t}+\beta_{6} X_{6 i t}+\varepsilon_{t}
$$

\section{FINDINGS AND DISCUSSION}

\section{The Achievement of Education Sector Development in Selayar Islands Regency}

The achievement of the Education Index in a region is determined by its educational development performance. Educational development aims to ensure the availability of education services that include all components related to education sector, including human resources, namely students and teachers, educational infrastructures such as schools, learning infrastructure, and others. Several indicators related to the availability of education services include the teacher to student ratio, the school to student ratio, and the class to student ratio, which are the independent variable in this study. Thus, the education indicators in Selayar Islands Regency, especially the variables in this study, generally have fluctuating achievements from year to year, as illustrated in Table 2.

Table 2. Achievements of Education Indicators for Selayar Islands Regency

\begin{tabular}{|c|c|c|c|c|c|c|}
\hline Year & $\mathbf{X}_{\mathbf{1}}$ & $\mathbf{X}_{\mathbf{2}}$ & $\mathbf{X}_{\mathbf{3}}$ & $\mathbf{X}_{\mathbf{4}}$ & $\mathbf{X}_{\mathbf{5}}$ & $\mathbf{X}_{\mathbf{6}}$ \\
\hline 2008 & 0.122 & 0.122 & 0.009 & 0.008 & 0.053 & 0.047 \\
\hline 2009 & 0.115 & 0.177 & 0.010 & 0.014 & 0.060 & 0.044 \\
\hline 2010 & 0.110 & 0.150 & 0.009 & 0.009 & 0.049 & 0.040 \\
\hline 2011 & 0.088 & 0.152 & 0.009 & 0.009 & 0.051 & 0.046 \\
\hline 2012 & 0.109 & 0.116 & 0.009 & 0.010 & 0.049 & 0.051 \\
\hline 2014 & 0.116 & 0.121 & 0.008 & 0.008 & 0.049 & 0.043 \\
\hline 2015 & 0.115 & 0.112 & 0.008 & 0.010 & 0.048 & 0.048 \\
\hline 2016 & 0.072 & 0.105 & 0.008 & 0.010 & 0.047 & 0.047 \\
\hline 2017 & 0.114 & 0.133 & 0.009 & 0.009 & 0.052 & 0.042 \\
\hline 2018 & 0.116 & 0.131 & 0.009 & 0.009 & 0.055 & 0.043 \\
\hline
\end{tabular}

\section{Analysis of Factors that Affect the Education Index}

\section{Estimation of Panel Data Regression Model}

The panel data regression model consists of three types of models: the Common Effect Model (CEM), Fixed Effect Model (FEM), and Random Effect Model (REM). The estimation results of the three models can be seen in Table 3 .

Table 3. Estimation Result of CEM, FEM, and REM

\begin{tabular}{|c|c|c|c|c|c|c|c|}
\hline \multirow{3}{*}{ No } & \multirow{3}{*}{ Variable } & \multicolumn{6}{|c|}{ Regression Model } \\
\hline & & \multicolumn{2}{|c|}{ CEM } & \multicolumn{2}{|c|}{ FEM } & \multicolumn{2}{|c|}{ REM } \\
\hline & & Statistics & Prob. & Statistics & Prob. & Statistics & Prob. \\
\hline 1 & $\mathrm{X}_{1}$ & 2.046691 & 0.0452 & -2.19797 & 0.0327 & -1.976374 & 0.0528 \\
\hline 2 & $\mathrm{X}_{2}$ & 0.409423 & 0.6837 & 0.648490 & 0.5197 & 0.348200 & 0.7289 \\
\hline 3 & $\mathrm{X}_{3}$ & -0.54278 & 0.5893 & 1.856542 & 0.0694 & 1.387706 & 0.1704 \\
\hline 4 & $\mathrm{X}_{4}$ & -2.75153 & 0.0004 & -1.42239 & 0.1612 & -2.821329 & 0.0065 \\
\hline 5 & $\mathrm{X}_{5}$ & 1.055067 & 0.2957 & 3.094697 & 0.0033 & 2.994592 & 0.0040 \\
\hline 6 & $\mathrm{X}_{6}$ & 1.084531 & 0.2825 & -0.33288 & 0.7406 & 0.022577 & 0.9821 \\
\hline \multicolumn{2}{|c|}{ R-squared } & \multicolumn{2}{|c|}{0.477352} & \multicolumn{2}{|c|}{0.926743} & \multicolumn{2}{|c|}{0.462315} \\
\hline \multicolumn{2}{|c|}{ Prob(F-Statistic) } & \multicolumn{2}{|c|}{0.000001} & \multicolumn{2}{|c|}{0.000000} & \multicolumn{2}{|c|}{0.000001} \\
\hline
\end{tabular}


From Table 3, it can be seen that the CEM estimation produces an R2 value of 0.477 and a prob (F-statistic) value of 0.000001, the FEM estimation produces an R2 value of 0.927 and a prob (F-statistic) value of 0.000000 , and the REM estimation model produces an R2 value of 0.462 and a prob (F-statistic) value of 0.000001 . Therefore, it can be said that the entire regression model produces two independent variables with a prob (t-statistic) value of less than the $5 \%$ significance level.

\section{Determination of the Best Panel Data Regression Model}

The best panel data regression model is determined using two tests: the Chow test and the Hausmann test. The Chow and Hausman test results in this study are through the Eviews 10 application, which can be seen in Table 4.

Table 4. The Results of the Chow Test and the Hausman Test of the Panel Data Regression Model

\begin{tabular}{ccc}
\hline Test & Statistics & Probability \\
\hline Chow Test & 129.685418 & 0.0000 \\
Hausmann Test & 13.893708 & 0.0308 \\
\hline
\end{tabular}

Based on the results of the Chow test as presented in Table 4, the resulting probability value is 0.0000 . It is less than the $5 \%$ significance level. Based on the results of the Chow test, it can be said that FEM is a better panel data regression model than the CEM model. Furthermore, in order to compare the FEM and REM, the Hausmann test was performed. Based on Table 3, the probability generated in the Hausman test is less than the 5\% significance level. Therefore, it indicates that the FEM model is better than the REM model. From this explanation, it can be concluded that the Fixed Effect Model (FEM) panel data regression model is the best model that can be used to estimate the factors that affect the Education Index in Selayar Islands Regency.

\section{The Result of the $F$ and $R^{2}$ Statistical Test}

The F statistical test is used to prove the hypothesis that all independent variables affect the dependent variable simultaneously. Meanwhile, the $\mathrm{R} 2$ test is used to determine how much influence all independent variables simultaneously have on the dependent variable. The results of the F test and R2 test in this study can be seen in Table 5 .

Table 5. The Tesults of the F Test and the $\mathrm{R}^{2}$ Factors that Affect the Education Index

\begin{tabular}{cccc}
\hline Model & F-statistic & Prob(F-statistic) & R Square \\
\hline Fixed Effect Model & 38.74223 & 0.000000 & 0.926743 \\
\hline
\end{tabular}

Based on Table 5, the statistical $F$ value is 38.742 , and the $F$ table value is 2.26 . Therefore, the statistical $\mathrm{F}$ value is more than the $\mathrm{F}$ table. In addition, the $\mathrm{F}$ statistical probability value of 0.000 is less than the significance level $\alpha(0.05)$. Thus, the previous research hypothesis is accepted, which means the variable of teacher to student ratio at elementary school, the ratio of teachers to students at junior high school, the ratio of schools to students at elementary school, the ratio of schools to students at junior high school, and the ratio of class to students at elementary school, the ratio of class to students at junior high school affect the Education Index simultaneously.

Furthermore, the R 2 value presented in Table 5 is 0.927 . This shows that all of the independent variables have an effect on the Education Index simultaneously by $92.7 \%$. In comparison, the remaining $7.3 \%$ is influenced by other variables besides the variables contained in this study. 
93 - Jalil S. Jamal, Muslim Salam, A. Nixia Tenriawaru, Didi Rukmana, Muhammad H. Jamil, \& Saadah

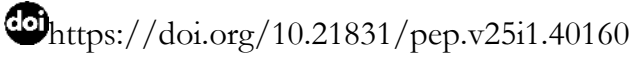

\section{The Results of Panel Data Regression Analysis and Statistical T Test}

Panel data regression analysis is used to test the effect of the variables expressed in the form of equations, and the $t$ statistical test is used to prove the hypothesis that all independent variables partially affect the dependent variable. The results of regression analysis with panel data and the t statistical test in this study are presented in Table 6.

Table 6. The Results of Panel Data Regression Analysis and T Statistical Test

\begin{tabular}{ccccc}
\hline Variable & T-statistic & Prob. & Coefficient & Std. Error \\
\hline $\mathrm{C}$ & & & 53.47487 & 2.204696 \\
$\mathrm{X}_{1}$ & -2.197974 & 0.0327 & -0.160864 & 0.073188 \\
$\mathrm{X}_{2}$ & 0.648490 & 0.5197 & 0.028767 & 0.044360 \\
$\mathrm{X}_{3}$ & 1.856542 & 0.0694 & 3.112364 & 1.676431 \\
$\mathrm{X}_{4}$ & -1.422394 & 0.1612 & -1.215816 & 0.854767 \\
$\mathrm{X}_{5}$ & 3.094697 & 0.0033 & 0.862743 & 0.278781 \\
$\mathrm{X}_{6}$ & -0.332877 & 0.7406 & -0.032869 & 0.098742 \\
\hline
\end{tabular}

After conducting panel data regression analysis in this study, the regression equation is obtained as in Formula (2). In addition, based on the regression equation and model estimation shown in Table 5, it can be seen and explained as follows.

$$
I P=53.475-0.160 X_{1}+0.029 X_{2}+3.112 X_{3}-1.216 X_{4}+0.863 X_{5}-0.033 X_{6} \ldots \ldots \ldots
$$

The variable of the teacher to student ratio at elementary school (X1) has a coefficient of -0.161. It shows that an increase of one percent of the teachers to students ratio at the elementary school will decrease the Education Index by 0.161 percent, assuming the other variables are constant. The $\mathrm{X} 1$ variable has a t count of 2.198. The value of the $\mathrm{t}$ count is more than the t table, which is 2.001 , and it is negative. Furthermore, the probability value of this variable is less than the $5 \%$ significance level. Therefore, the teacher to student ratio variable at the elementary school has a negative and significant effect on the education index variable.

The variable of the teacher to student ratio at junior high school (X2) has a coefficient of 0.029 . It shows that an increase of one percent of the teachers to students ratio at the junior high school will increase the Education Index by 0.029 percent, assuming the other variables are constant. However, the X2 variable does not affect the Education Index because the probability value more than the $5 \%$ significance level.

The variable of the school to student ratio at elementary school (X3) has a coefficient of 3.112. It shows that an increase of one percent of the schools to students ratio at the elementary school will increase the Education Index by 3.112 percent, assuming the other variables are constant. Furthermore, the X3 variable does not affect the Education Index because the probability value is more than the $5 \%$ significance level.

The variable of the school to student ratio at junior high school (X4) has a coefficient of -1.216. It shows that an increase of one percent of the schools to students ratio at the junior high school level will reduce the Education Index by -1.216 percent, assuming the other variables are constant. Furthermore, the X4 variable does not affect the Education Index because the probability value is more than the $5 \%$ significance level.

The variable of the class to student ratio at elementary school (X5) has a coefficient of 0.863. It shows that an increase of one percent of the class to students ratio at the elementary school level will reduce the Education Index by 0.863 percent, assuming the other variables are constant. Furthermore, The X5 has a t count of 3.094. The value of the t count is more than the $\mathrm{t}$ table, which is equal to 2.001, and it is positive. Furthermore, the probability value of this variable is less than the $5 \%$ significance level. Therefore, it can be concluded that the Class to Student Ratio variable at the elementary school has a positive and significant effect on the Education Index variable. 
94 - Jalil S. Jamal, Muslim Salam, A. Nixia Tenriawaru, Didi Rukmana, Muhammad H. Jamil, \& Saadah

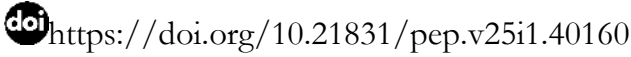

The variable of the class to student ratio at the junior high school (X6) has a coefficient of -0.033 . This shows that an increase of one percent of the class to students ratio at junior high school level will reduce the Education Index by -0.033 percent, assuming the other variables are constant. However, the X6 variable does not affect the Education Index because the probability value more than the 5\% significance level.

\section{Factors that Affect the Education Index Improvement}

Based on the previous explanation and analysis, there are some factors that influence the Education Index that contribute to the HDI improvement. Each factor is elaborated as follows.

\section{The Ratio of Teacher to Student at Elementary School}

Based on the previous analysis, the teacher to student ratio at the elementary school has a negative and significant effect on the Education Index. It means that increasing the ratio of teachers to students at elementary school will decrease the Education Index in Selayar Islands Regency.

The results of this study are not in accordance with the results of the previous study of Sapaat et al. (2020), which state that the ratio of teachers to students has a positive effect on HDI in North Sulawesi Province, and the result of a study by Mahendra et al. (2016), that the ratio of teachers to students at the elementary school has a positive and significant effect on the Education Index in East Java Province. This situation is caused by the number of teachers at the elementary school is overload compared to the number of students in Selayar Islands Regency.

As it is well known, the ratio of teachers to students at elementary school in Selayar Islands Regency during the period 2008 to 2019 exceeds the National Education Standard that has been established by the Ministry of Education and Culture. In 2019, the ratio of teachers to students at elementary school in Selayar Islands Regency reached 1:9, which means that one teacher supports nine students. It does not meet the standard that is established by the Ministry of Education and Culture, in which it is regulated that each elementary school has one teacher supporting 32 students. Based on the data obtained from the Ministry of Education and Culture, in 2019, Selayar Islands Regency has an excess of 289 teachers at the elementary school.

The problem of the excessive ratio of teachers to students at elementary school is inversely proportional to the problem that is experienced by the Selayar Islands Regency for several years, namely the shortage of civil servant teachers, especially in the island region. It is because the Selayar Islands Regency has an excess of non-civil servant teachers. This excess number of the non-civil servant teachers, followed by the lack of civil servant teachers, will certainly contribute to the less than optimal quality of the teachers. As it is commonly known, the quality and also capability of the civil servant teachers will be higher when compared to non-civil servant teachers. In addition, the large number of non-civil servant teachers will cause civil servant teachers not to fulfill their duties optimally, and they sometimes delegate their responsibilities to non-civil servant teachers. It certainly will affect the decline in the quality of education, which will lead to the failure in the achievement of the Education Index improvement.

Therefore, based on the results of this study, in order to improve the education index, which will contribute to HDI improvement, the teacher to student ratio at elementary school must be reduced by reducing the number of non-civil servant teachers in elementary school. In addition, it also will streamline and make effective use of the budget for the payment of the non-civil servant teachers' salaries. 
95 - Jalil S. Jamal, Muslim Salam, A. Nixia Tenriawaru, Didi Rukmana, Muhammad H. Jamil, \& Saadah

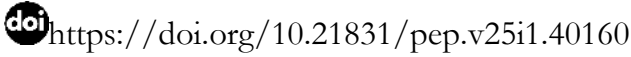

The Ratio of Class to Student at Elementary School

The class to student ratio variable at elementary school is related to the availability of elementary school classrooms in a region compared to the number of elementary school students in that region. Based on the previous analysis, the class to student ratio at elementary school has a positive and significant effect on the Education Index. This means that the improvement of the class to student ratio at elementary school is directly proportional to the improvement of the Education Index in Selayar Islands Regency. The results of this study are in line with the result of the study by Cahyadi (Syamsuri \& Bandiyono, 2018), which states that the ratio of the number of students at elementary school to the number of classrooms at elementary school has a positive and significant effect on HDI.

Selayar Islands Regency has launched a compulsory education program for at least nine years, in which there are activities such as building new classrooms and rehabilitating classrooms to support the learning process. Compulsory education of at least nine years will be realized if only educational facilities such as classrooms as a place for learning and interaction between teachers and students are available and in good quality. In other words, the role of the classroom is crucial in the educational process because the availability of a good and comfortable classroom will affect the continuity of the educational process (Hambali, 2016).

When the view from the number of classrooms at elementary school is in good condition, the performance increased from 160 classrooms in 2015 to 745 classrooms in 2019. The availability of educational facilities and infrastructure, especially adequate classrooms, will motivate the community to take advantage of these educational facilities and participate in the learning process (Syamsuri \& Bandiyono, 2018). The increase of community participation in the education process in schools is very influential in improving the average length of schooling and the number of years of schooling, which are components of the calculation of the Education Index (Syamsuri \& Bandiyono, 2018).

\section{CONCLUSION}

From this research, it can be concluded that the factors that affect the education index improvement are as follows. The ratio of teachers to students at the elementary school has a negative and significant effect on the education index improvement. Besides, the class ratio to students at the elementary school has a positive and significant effect on the education index improvement in the Selayar Islands Regency.

\section{REFERENCES}

Ajija, S. R. (2011). Cara cerdas menguasai EViews. Salemba Empat.

Aulia, T. (2004). Modul pelatihan Ekonometrika. Fakultas Ekonomi dan Bisnis Universitas Airlangga.

Cahill, M. B. (2005). Is the human development index redundant? Eastern Economic Journal, 31(1), 1-5. http://www.jstor.org/stable/40326318

Gujarati, D. (2003). Ekonometri dasar (S. Zain (trans.)). Erlangga.

Hambali, H. (2016). Pembangunan gedung sekolah dan ruang kelas baru di Kabupaten Seluma pasca pemekaran. Manajer Pendidikan, 10(1), 20-28. https://ejournal.unib.ac.id/index.php/manajerpendidikan/article/view/1229

Lestari, W. W., \& Sanar, V. E. (2018). Analysis indicator of factors affecting human development index (IPM). Geosfera Indonesia, 2(1), 11-18. https://doi.org/10.19184/geosi.v2i1.7333 
Mahendra, R., Fariyanti, A., \& Falatehan, A. F. (2016). Strategi peningkatan indeks pendidikan melalui alokasi belanja pemerintah daerah bidang pendidikan di Provinsi Jawa Timur. Jurnal Manajemen Pembangunan Daerah, 8(2), 1-19. https://doi.org/10.29244/jurnal_mpd.v8i2.24823

Mirza, D. S. (2011). Pengaruh kemiskinan, pertumbuhan ekonomi, dan belanja modal terhadap IPM Jawa Tengah. JEJAK: Jurnal Ekonomi Dan Kebijakan, 4(2), 102-113. https://journal.unnes.ac.id/nju/index.php/jejak/article/view/4645

Sapaat, T. M., Lapian, A. L. C. P., \& Tumangkeng, S. Y. L. (2020). Analisis faktor-faktor yang mempengaruhi indeks pembangunan manusia di Provinsi Sulawesi Utara tahun (20052019). Jurnal Berkala Ilmiah Efisiensi, 20(03), 45-56. https:// journal.unsrat.ac.id/index.php/jbie/article/view/30641

Sugiarta, I. M., Mardana, I. B. P., Adiarta, A., \& Artanayasa, W. (2019). Filsafat pendidikan Ki Hajar Dewantara (Tokoh timur). Jurnal Filsafat Indonesia, 2(3), 124-136. https://doi.org/10.23887/jfi.v2i3.22187

Sukarsa, I. M. (2012). Pemetaan kualitas pendidikan di Propinsi Bali berbasis spatial. Majalah Ilmiah Teknologi Elektro, 8(1), 6-11. https://ojs.unud.ac.id/index.php/JTE/article/view/1570

Sunarya, I. W. (2016). Analisis pembangunan sumber daya manusia di Provinsi Bali tahun 2011-2014. Jurnal Aplikasi Manajemen, 14(3), 577-584. https://doi.org/10.18202/jam23026332.14.3.18

Syamsuri, M. R., \& Bandiyono, A. (2018). Pengaruh belanja pemerintah daerah berdasarkan fungsi terhadap peningkatan IPM dan pengentasan kemiskinan (Studi pada kabupaten/kota di Provinsi Aceh). Info Artha, 2(1), 11-28.

Verbeek, M. (2000). A guide to Modern Econometrics. John Willey \& Sons.

Wibisono, D. (2005). Metode penelitian \& analisis data. Salemba Medika. 